\title{
STRESS ECOLOGY IN MINING LANDSCAPE: POSTINDUSTRIAL DEPOSITS IN COMPARISON WITH THEIR SURROUNDINGS AS THE ENVIRONMENTS FOR SELECTION OF PLANTS WITH SMALL AND LARGE GENOME SIZE
}

\section{(A CONTRIBUTION TO ECOLOGICAL GENOMICS AND RESTORATION ECOLOGY)}

\section{(SHORT COMMUNICATION)}

\author{
ADAM GLIER ${ }^{1}$, ROMANA PRAUSOVÁ ${ }^{2}$, MiCHAL ŠTEFÁNEK ${ }^{1,2}$, \\ PAVEL KOVÁR ${ }^{1 *}$
}

\begin{abstract}
${ }^{1}$ Department of Botany, Faculty of Science, Charles University in Prague, Benátská 2, 12801 Praha 2,e-mail: kovar@natur.cuni.cz.

${ }^{2}$ Department of Biology, Faculty of Science, University of Hradec Králové, Rokitanského 62, 50003 Hradec Králové

*Corresponding author e-mail: pavel.kovar@natur.cuni.cz
\end{abstract}

Received: $18^{\text {th }}$ October 2020 , Accepted: $10^{\text {th }}$ November 2020

\begin{abstract}
This pilot case study compares genome sizes of two groups of species (conspecific plants) which spontaneously colonize interior space within abandoned industrial area and/or deposits, and those ones occurred in adjacent vicinity. Testing of the hypothesis "There is functional significance of small versus large genomes of plant species by comparing their occurrence in unreclaimed toxic deposits as an example of stressed environment and in their populations from neighbouring habitats" confirmed this idea.
\end{abstract}

Keywords: unreclaimed industrial deposits in landscape, abandoned mine tailings, genome size, flow cytometry, conspecific taxons, plant traits, colonization, succession, disturbance, stress, restoration ecology, ecological genomics

\section{BACKGROUND OF THE STUDY}

Knowledge of natural processes influencing recovery of postindustrial deposits in landscapes plays a key role in development of innovative concepts within restoration ecology. New ideas and hypotheses for testing in the field are coming from the sphere of molecular ecology, ecological genetics and/or genomics and also stress ecology in the frame of ecotoxicology. By this way, the results of interdisciplinary research offer both basic scientific outputs and application in practice of landscape management. Our contribution presents some results of small case study following the set of previous studies concentrated on abandoned mine tailings mainly concentrated on the mechanisms of vegetation succession 
and colonization of the ore-waste deposits with ecologically extreme parameters (Kovár, 2004; Neustupa et al., 2008; Štefánek et al., 2012; Štefánek, 2015; Prausová et al., 2017; Urbanová et al., 2017; Dvořáčková et al., 2018).

\section{HABITAT LOCALITY AND MATERIAL}

Sampling of data was placed in the most investigated postindustrial locality in the Czech Republic with longest known history (50 years) of the all registered comparable localities where huge number of original data from previous studies is available (e.g., Kovár, 2004; Štefánek, 2015; Urbanová et al., 2017; Prausová et al., 2017) - ore-washery sedimentary basin near Chvaletice, Eastern Bohemia, 50 02'12"N, 15²6'15"E). The main interest during last decades was concentrated on mechanisms of primary vegetation succession. In the frame of total number of approx. 300 identified plant species in the locality (within the period: 2014 - 2019) a sufficient number of pairs and/or groups (67) of the conspecific taxons (134) occurred inside the deposit and behind its edge in the surroundings was sampled and compared in genome size.

\section{Measurement of $\mathrm{C}$-values by the the flow cytometry method:}

Genome size (C-values, i. e., amount of holoploid nuclear DNA in a single cell) was estimated using propidium iodide flow cytometry (using Partec Cyflow instruments equipped with 532-nm solid state laser). Fresh leaf tissue of plant samples was processed together with a suitable internal reference standard (Doležel et al., 2007). C-value in the case of polyploids is necessary to multiply by the number of chromosomal sets (Van Straalen et Roelofs, 2011). It is presented in picograms (pg). At least three replicates on different days were performed for genome size measurements. Differences in C-values between species from unreclaimed industrial deposits and their conspecific counterparts were ensured for testing of the initial hypothesis. Plant species in order of tens from unreclaimed industrial deposits covering a range of plant families, life forms and plant life strategies were analyzed in addition to at least the same number of species from neighbouring natural habitats.

\section{GENOMES OF PLANTS IN OPEN ORE-WASTE SUBSTRATE AND BEHIND THE EDGE OF TAILINGS CONTAINMENT}

Our research started with the hypothesis that adaptive plant (sub)dominants selected by the site's harsh environmental conditions are represented by species with small genome size within specifically delimited variability. According some earlier studies there is an evidence that the amount of DNA in the genome may have considerable biological effects on organisms independent of the encoded genetic information (e.g., Bureš et al., 2004; Kubešová et al., 2010), however, variation in genome size has only rarely been integrated into ecological interpretations and it is needed to assess the functional significance of small versus large genomes by comparing, in a phylogenetic framework. Genome sizes of species occurring in unreclaimed postindustrial deposits with their related counterparts from natural habitats can provide good opportunity to test this idea. In other words: we do the interspecific comparison as relevant level for given scale. Supporting facts from previous field measurements at the locality led to present considerations: Weathering of deposited waste material of the ore mining origin consists of oxidizing pyritic materials and produces sulphate type of soils - extreme $\mathrm{pH}$ values, high sulphur and phenol contents complicate spontaneous processes leading to natural recovery. The soil surface is moderately 
Glier A., Prausová R., Štefánek M., Kovář P.: Stress ecology in mining landscape: postindustrial deposits in comparison with their surroundings as the environments for selection of plants with small and large genome size

consolidated by salt efflorescences (from gypsum and jarosite) and the substrate development greatly varies over the former sedimentation space, according to its microtopography determined by oxidation of sulphides and leaching of salts (Rauch, 2004). Secondary salt accumulation is seriously determined by the length of dry periods in the vegetation season (Hroudová et Zákravský, 2004). A strongly cemented horizon with red ferric oxides and gypsum developed at lower depths of soil profiles (Mrázek, 2004; Kovář et al., 2011) and caused retrogradation in successional progress through periodical extinction od the tree seedlings (Kovář et Herben, 2004). Repeated restoration of initial colonization with biota includes the microhabitat dynamics at small-scale level (creation of biological soil crust) and processes of the organic matter decomposition (litter fall, dead biomass supply), bioturbation activity of the soil fauna, establishment of plant seeds and their seedlings or the insect/plant interactions, seed dispersal by zoochory and anemochory improve and use the environmental properties in the mosaic of microsites and shift the ecosystem far towards life-supporting state of spontaneous balanced succession (Kovár, 2004; Neustupa et al., 2009; Stefánek et al., 2012; Dostál et Kovář, 2013; Kovář et al., 2013). Hence, above mentioned contradictions imply irregular shifts in vegetation succession on toxic postindustrial wastes and differentiated qualitative composition of plant stands inside and outside the deposited substrate body. Genome size is only one of traits of plants from the local species pool (Figs. 1 and 2).

Fig. 1: Graph using point interpretation of mutual relationship among genome sizes in the frame of related groups of plant species. It includes 67 points representing various species combinations, inside relational group in every cases. The point position in upper part of the graph (i. e., above diagonal line) suggests the tendency of plants growing in surroundings of the tailings containment to have a larger genome.

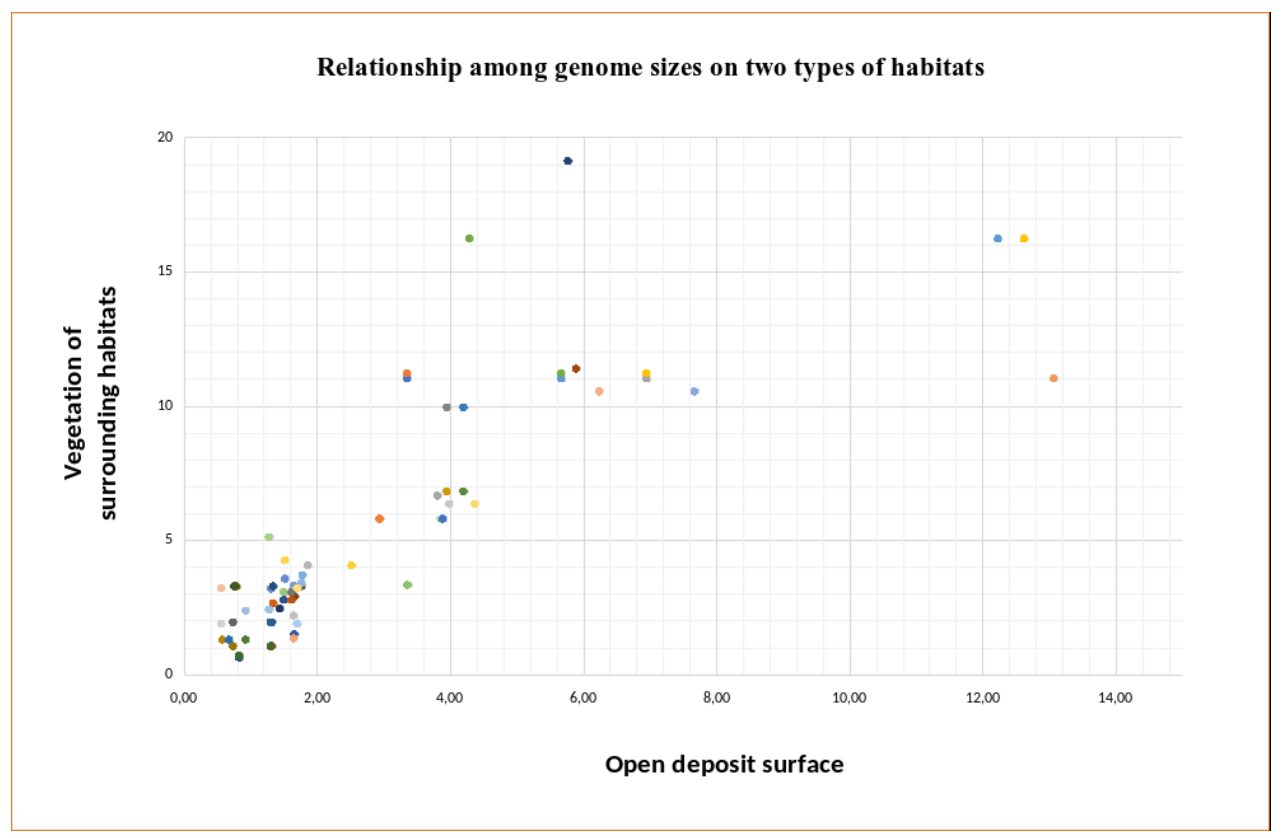


Results confirm the initial hypothesis on the adaptive preference of small genomes in ecologically stressed environment in long-term open habitat of the mine tailings (Glier, 2019).

Fig. 2: A line chart that shows trends in values from one or more sets of data connected by lines. Position on the left represents the genome size of plants growing inside the abandoned tailings containment in its open parts, position on the right is comprised by plants occurred in close surroundings of the deposit body. Difference in genome sizes in the intrageneric related species is expressed by inclination of connecting lines.

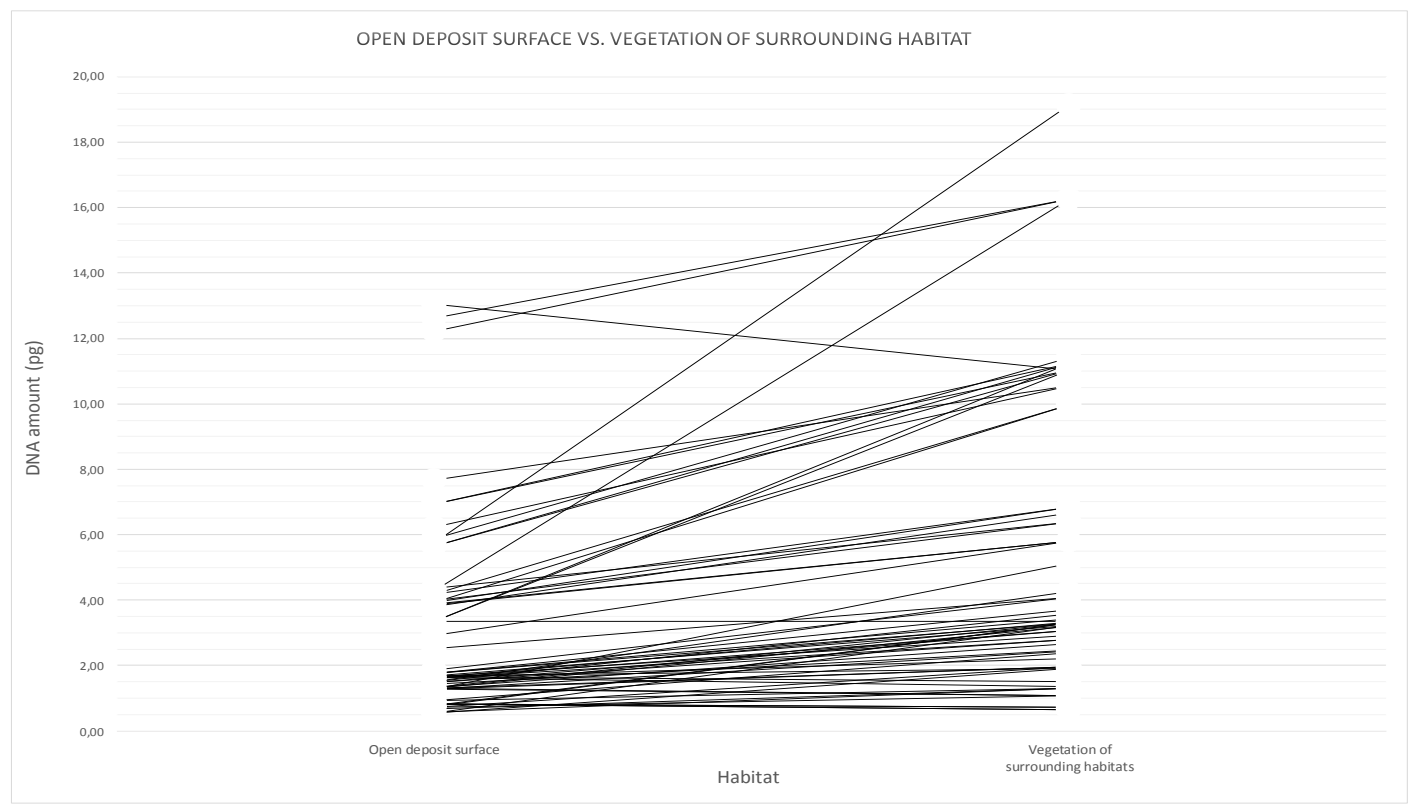

\section{Conclusions}

Study of genome size of plants colonizing different habitat types in tle postindustrial locality of mine tailings (abandoned sedimentation deposits) within cultural lowland landscape shows that hypothesis about small genomes inside the toxic ore-waste deposit versus large genomes of related plant species outside this artificial ecosystem is valid. This fact suggests that genome parameter as one of important traits of plants has both indication significance for degree of stress-tolerance or resistance to disturbance resistant of plants and potential for selection of suitable combination of plants accelerating process of colonization and vegetation succession.

\section{ACKNOWLEDGEMENTS}

We thank to T.Urfus (Dept. Botany, Fac. Science, Charles Univ.) for enabling to provide cytometric analyses of plants in the Laboratory of flow cytometry and to M. Weiser (Dept. Botany, Fac. Science, Charles Univ.) for statistical consultations. Thanks also belong to A. 
Glier A., Prausová R., Štefánek M., Kovář P.: Stress ecology in mining landscape: postindustrial deposits in comparison with their surroundings as the environments for selection of plants with small and large genome size

Burešová, P. Dostál, J. Urbanová, O. Rauch and students for the help with the field collection of data.

\section{REFERENCES}

Bureš, P., Wang, Y.-F., Horová, L., Suda, J. (2004). Genome size variation in Central European species of Cirsium (Compositae) and their natural hybrids. - Annals of Botany 94: 353-363.

Doležel, J., Greilhuber, J., Suda, J. (2007). Flow cytometry with plant cells, analysis of genes, chromosomes and genomes. John Wiley \& Sons.

Dostál, P., Kovář, P. (2013). Seed rain and seed persistence of Calamagrostis epigejos. (L.) Roth in extreme ecotoxicological conditions as an abandoned ore-washery sedimentation basin. - Journal of Landscape Ecology, 6(2): 17-33.

Dvořáčková, M., Pech, P., Prausová, R., Horák, J. (2018). Diversity of ant community in ore sedimentation basin under different regimes of reclamation. Polish Journal of Ecology. 66(2), 139-152.

Glier, A. (2019). Comparison of selected traits at conspecific plants in disturbed and stressed environments localized within industrial waste deposits and their surroundings in landscape. - Ms., 2019 (Bc-thesis, Department of Botany, Faculty of Science, Charles University, Prague, Czech Republic)[in Czech]

Greilhuber, J., Doležel, J., Lysak, M.A., Bennett, M.D. (2005). The origin, evolution and proposed stabilization of the terms 'genome size' and 'C-value' to describe nuclear DNA contents. - Annals of Botany, 95(1), 255-260.

Hroudová, Z., Zákravský, P. (2004). The influence of the moss layer on soil surface microclimate in an abandoned ore-washery sedimentation basin. - In: Kovár̆, P. (ed.): Natural Recovery of Human-Made Deposits in Landscape (p. 235-247) (Biotic Interactions and Ore/Ash-Slag Artificial Ecosystems) - Academia, Prague.

Kovář, P. (ed.) (2004). Natural Recovery of Human-Made Deposits in Landscape (Biotic Interactions and Ore/Ash-Slag Artificial Ecosystems) - Academia, Prague.

Kováŕ, P., Herben, T. (2004). Small-scale spatiotemporal dynamics of plant cover during the initial phase of primary succession in an abandoned ore-washery sedimentation basin. - In: Kováŕ P. (ed.): Natural Recovery of Human-Made Deposits in Landscape (p. 277-284) (Biotic Interactions and Ore/Ash-Slag Artificial Ecosystems) - Academia, Prague.

Kovár, P., Štefánek, M., Mrázek, J. (2011). Responses of vegetation stages with woody dominants to stress and disturbance during succession of abandoned tailings in cultural landscape. - Journal of Landscape Ecology, 4(2): 35-48.

Kovář, P., Vojtíšek, P., Zentsová, I. (2013). Ants as ecosystem engineers in natural restoration of human made habitats. - Journal of Landscape Ecology, 6(1): 18-31.

Kubešová, M., Moravcová, L., Suda, J., Jarošík, V., Pyšek, P. (2010). Naturalized plants have smaller genomes than their non-invading relatives: a flow cytometric analysis of the Czech alien flora. - Preslia 82: 81-96.

Mrázek J. (2004). Comparison of the growth of dominant trees (Betula pendula, Populus tremula) in primary succession on toxic substrate. - In: Kovár P. (ed.): Natural Recovery of Human-Made Deposits in Landscape (p. 294-299) (Biotic Interactions and Ore/Ash-Slag Artificial Ecosystems) - Academia, Prague. 
Neustupa, J. et al. (2009). The biological soil crusts in Central European ecosystems, with special reference to taxonomic structure and ecology of the surface crusts at Czech ore-waste and ash-slag sedimentation industrial basins. - Novitates Botanicae Universitatis Carolinae, 19/2008: 9-99.

Prausová, R., Štefánek, M., Rauch, O., Kovář, P. (2017). Trees as ecosystem engineers driving vegetational restoration/retrogradation of industrial deposits in cultural landscape. Journal of Landscape Ecology, 10(2): 122-131.

Rauch, O. (2004). Genesis and characteristics of orewaste sulphate soils at Chvaletice. - In: Kováŕ P. (ed.): Natural Recovery of Human-Made Deposits in Landscape (p. 45-58) (Biotic Interactions and Ore/Ash-Slag Artificial Ecosystems) - Academia, Prague.

Štefánek, M. (2015). Role of plant dominants on abandoned tailings containment from manganese-ore mining in Chvaletice, Eastern Bohemia, Czech Republic (Overview of long-term case studies.). - Journal of Landscape Ecology, 8(3): 92-97.

Štefánek, M., Kovář, P., Dlouhá, V. (2012). Role of fire episode, leaf litter decomposition and mulching effects in restoration of the surface soil crust microecosystem on abandoned tailings containment. - Journal of Landscape Ecology, 5(3): 57-69.

Urbanová, J., Kováŕ, P., Dostál, P. (2017). What processes shape early-successional vegetation in fly ash and mine tailings? - Plant Ecology, 218(2): 127-137.

Van Straalen, N. M., Roelofs, D. (2011). An introduction to ecological genomics. OUP, Oxford. 